\title{
Community Design Parameters and the Performance of Residential Cogeneration Systems
}

\author{
Hazem Rashed-Ali, Ph.D. \\ University of Texas at San Antonio, San Antonio, TX
}

\begin{abstract}
The integration of cogeneration systems in residential and mixed-use communities has the potential of reducing their energy demand and harmful emissions and can thus play a significant role in increasing their environmental sustainability. This study investigated the impact of selected planning and architectural design parameters on the environmental and economic performances of centralized cogeneration systems integrated into residential communities in U.S. cold climates. Parameters investigated include: 1) density, 2) use mix, 3) street configuration, 4) housing typology, 5) envelope and building systems' efficiencies, and 6) passive solar energy utilization. The study integrated several simulation tools into a procedure to assess the impact of each design parameter on the cogeneration system performance. This assessment procedure included: developing a base-line model representing typical design characteristics of U.S. residential communities; assessing the cogeneration system's performance within this model using three performance indicators: percentage of reduction in primary energy use, percentage of reduction in $\mathrm{CO}_{2}$ emissions; and internal rate of return; assessing the impact of each parameter on the system performance through developing 46 design variations of the base-line model representing potential changes in each parameter and calculating the three indicators for each variation; and finally, using a multi-attribute decision analysis methodology to evaluate the relative impact of each parameter on the cogeneration system performance. The study results show that planning parameters had a higher impact on the cogeneration system performance than architectural ones. Also, a significant correlation was found between design characteristics identified as favorable for the cogeneration system performance and those of sustainable residential communities. These include high densities, high use mix, interconnected street networks, and mixing of housing typologies. This indicates a higher potential for integrating cogeneration systems in sustainable communities.
\end{abstract}

Keywords: cogeneration; residential \& mixed use communities; energy efficiency; district heating

\section{SUSTAINABILITY, THE BUILT ENVIRONMENT, AND COGENERATION}

In the past three decades, the need for adopting the principles and practices of sustainability has been clearly established through research activities, political conventions, and protocols. While a lack of consensus still exists over the definition of sustainable development and the issues it should address, existing schools of thought agree over the need for balancing its three main components: environmental, economic, and social sustainability. The need for environmental sustainability stems from the growing sense of responsibility motivated by the realization of the serious environmental problems facing world communities (e.g. global warming, resources depletion, increased pollution, etc.). Energy is a central issue in the sustainability debate affecting all three of its components (Johansson \& Goldemberg 2002). This wide impact of energy indicates that energy efficiency, while perhaps not a sufficient condition for sustainability, is certainly a necessary one. The built environment plays a major role in the U.S. energy system both directly, through energy use in the residential and commercial sectors, which in 2004 accounted for $21.2 \%$ \& $17.5 \%$ of total U.S. consumption respectively (EIA 2005), and indirectly, through its impact on the transportation sector, which accounted for an additional $27.8 \%$ of that consumption (EIA 2005). Subsequently, increasing energy efficiency in the built environment can positively impact its sustainability. Numerous studies conducted on the relations among sustainability, urban form, and building design, some of which are listed in the coming section, indicate a clear potential for achieving significant reductions in energy consumption through intelligent and sustainable planning and architecture. Increasing the energy efficiency of new residential communities is of particular significance in light of the projected increases in residential energy use due to increases in population and new housing stock. However, statistics show that the majority of the new U.S. housing stock are detached single family houses that are typically larger in size and 
consume more energy than current average U.S. homes. Such trends would further increase the environmental impact of the residential sector. A clear need, therefore, exists for research activities that aim to explore alternative design strategies, characteristics, systems, and technologies that aim to increase the energy efficiency and reduce the energy demand of the residential sector.

Electricity production resulted in 39\% of energy-related U.S. $\mathrm{CO}_{2}$ emissions in 2003 (EIA 2004). Distributed generation (DG) is an established alternative to existing power systems that has the potential of achieving considerable environmental and economic benefits. The use of cogeneration, a technology that generates electricity locally and utilizes the thermal energy byproduct of the generation process in thermal end uses such as space and water heating, further increases the efficiency and the potential benefits of DG. Combined with energy conservation measures, residential cogeneration systems offer the potential for meeting most or all of the energy needs of residential communities in a more economic and environmentally friendly manner. Consequently, integrating cogeneration technologies into new residential communities can mitigate the expected increases in their environmental impact. Residential cogeneration systems are currently utilized in several European communities (e.g. Kronsberg Community in Hannover, Germany; and Beddington Zero Energy Development in London, UK). In the U.S., however, while cogeneration is well established in many sectors, e.g. the industrial and educational ones, its use in the residential sector is still very limited in spite of the significant energy and emissions reductions potential that this technology presents (see Gunes \& Ellis 2003; Braun et al. 2004). One of the main reasons cited for this limited use is the high initial system cost, especially for district heating networks (Phetteplace 1995), as well as the unsuitability of the energy use characteristics of conventional U.S. residential communities (with their high daily and seasonal variations) to the needs of cogeneration systems. A number of possible strategies for increasing the use of residential cogeneration have been discussed in the literature, one of which is to identify potential residential markets with more suitable energy use characteristics that can act as market entry points for these technologies (U.S. DOE, 2003).

Throughout the U.S., a number of new, sustainable, residential communities are being developed, which attempt to integrate the principles of sustainability and energy efficiency from the early stages of their design. The design characteristics of these communities are considerably different from those of conventional ones thus resulting in improved energy use characteristics. These communities are also used to demonstrate the performance of emerging technologies. While their number is still limited, such communities represent a potential market for the integration of cogeneration systems. This integration can result in further reductions in the communities' environmental impact as well as to wider acceptance of these emerging technologies and improvements in their economics making them suitable for other markets. Therefore, a need exists to investigate the impact of the different design characteristics of sustainable communities, compared to those of conventional ones, on the performance of the cogeneration systems and therefore on their feasibility. Such studies can then be used to develop design guidelines that can inform designers of sustainable communities who wish to integrate cogeneration into their projects. As the design of residential communities utilizing cogeneration systems involves a large number of parameters on the planning and architecture scales, this study focused on selected parameters on each scale and assessed their individual impact on the performance of cogeneration system. These selected parameters are: 1) density, 2) use mix, 3) street configuration, 4) housing typology, 5) envelope and building systems' efficiencies, and 6) passive solar energy utilization. This assessment aims to demonstrat the impact that informed design can have on increasing the feasibility of emerging technologies, such as residential cogeneration, and therefore on improving the environmental impact of residential communities. In this context, the following sections will present a brief literature review dealing with sustainability, how it relates to the built environment, distributed generation and cogeneration, and performance assessment studies of residential cogeneration. Subsequently, the methodology used in assessing the design parameters' impact on the cogeneration system performance will be described followed by a summary and analysis of the assessment results. Finally, several conclusions that can be drawn form these results will be outlined and discussed.

\section{LITERATURE REVIEW}

\subsection{Sustainability, energy, and the built environment}

While varying in emphasis, existing definitions of sustainability and sustainable development (e.g. WCED 1987) all stress the need for balancing environmental, economic and social considerations while maintaining a good quality of life. A strong and direct link exists between environmental sustainability: including issues of mitigation of existing environmental problems, protection of eco-systems, more efficient use of natural resources, and biodiversity; and between energy and energy systems. Johansson \& Goldemberg (2002) describe conventional sources of and approaches to providing and using energy as unsustainable and link them to significant environmental, social, and health problems both currently and in the future. They also suggest several alternative strategies to achieve a more sustainable energy including: more efficient use of energy; accelerated development and deployment of new energy technologies; decentralization of the world energy systems; and increased use of renewable energy resources. Increasing the environmental sustainability of the built 
environment, through more efficient use of resources and reduced environmental impact, is a major component of sustainable development and increasing energy efficiency is a necessary requirement for achieving that goal. Many studies conducted on the relations among sustainability, urban form, and building design (e.g. Breheny, 1992; Owens, 1986; Williams et al., 2000) indicate a considerable potential for increasing the energy efficiency of the built environment through intelligent and sustainable design. Grumman (2003) further argues that this potential is considerably larger when sustainability principles are applied in the early stages of the design process. Additionally, Barton (2000) argues that sustainable communities, many of which are currently in different stages of development throughout the U.S., can change the prevailing culture of local decision makers, professionals, and developers. These communities also offer a considerable opportunity for demonstrating emerging technologies under more favorable conditions.

\subsection{Distributed generation \& residential cogeneration}

Distributed generation can offer several advantages compared to centralized systems. WADE (2003) identifies these advantages as: 1) lower $\mathrm{CO}_{2}$ emission; 2) lower costs; 3) lower transmission and distribution losses; 4) greater power quality; and 5) less system vulnerability. Houghton (2000), arguing for developing small scale and locally-based community energy utilities, contended that such utilities can be a vital element of new sustainable communities offering many societal benefits including raising awareness of the consequences of energy use, increasing social responsibility, and improving local economy through lowering energy costs and providing local employment. Two approaches can be identified in the literature for integrating cogeneration systems in residential communities, to be described here as the centralized and the decentralized integration approaches. Centralized integration involves a central plant supplying electricity, heating and possibly cooling to a number of buildings through electrical distribution and district heating/cooling (DHC) networks (see Phetteplace, 1995). While decentralized integration is a newer alternative, in which smaller-sized micro-cogeneration systems are integrated into individual homes. Centralized integration utilizes larger sized, more established, and more efficient technologies, yet its economic performance is negatively impacted by the high initial cost and thermal losses of the DHC networks. On the other hand, micro-cogeneration technologies, while avoiding the penalties associated with DHC networks, are currently still lower in efficiency and higher in initial cost (per unit power) than their larger-sized counterparts (Knight and Ugursal 2005). In both approaches, the systems are mostly gridconnected and include a supplementary heating source. While the majority of existing cogeneration systems utilize conventional fossil fuels, e.g. natural gas, some existing systems utilize alternative, more renewable, fuels and the use of fuel cells in particular offers a large potential in this regard. The study reported in this paper, however, focuses on the more established centralized integration approach using natural gas.

\subsection{Performance assessment of residential cogeneration systems}

Higher awareness of the environmental implications of current energy systems and the potential impact of residential cogeneration on the sustainability of the residential sector, combined with recent advances in cogeneration technologies, have resulted in increased research activities in the area which aim to investigate the current potential for residential cogeneration systems, their benefits, and the optimum conditions under which they can be utilized. Conventional feasibility studies of cogeneration systems (e.g. Ellis 2002) have been limited to economic performance, i.e. identifying the optimum design characteristics of the cogeneration system (e.g. system type, size, operation strategy, configuration, etc.), which would achieve the maximum possible economic return over the project life cycle. However, the majority of recent studies (e.g. Gunes \& Ellis 2003; Braun et al. 2004), which recognize the sustainability implications of these systems, have considered both economic and environmental impacts of the technology. In general, most studies addressing both environmental and economic performances of residential cogeneration show the potential for significant energy and environmental benefits from using the technology. However, the majority of these studies also generally agree that the economics of the technologies are still uncompetitive with conventional systems mainly because of their higher initial cost as well as the current low cost of electricity. However, most existing studies exclusively dealt with the issue at the scale of the individual building and not that of the community, and they also did not investigate the impact that improving the energy use characteristics of buildings, communities, or both can have on the energy use, and consequently the performance of the cogeneration system. Additionally, few studies have been conducted that aim to identify suitable markets for residential cogeneration, a goal identified as important for the wider use of the technology (U.S. DOE 2003). This study, while adopting a similar approach in assessing both the environmental and economic performances of residential cogeneration, using the concept of performance indicators, represents an attempt to investigate these issues thus addressing these gabs in the literature.

\section{METHODOLOGY}

This study utilized a quantitative research methodology, in which building energy simulation and cogeneration system performance simulation tools were used to investigate the impact of the selected design parameters on the performance of the cogeneration system. The research design, shown in figure 1, included developing a base-line model representing the design characteristics of conventional U.S. residential communities (see table 1 
for model and cogeneration system characteristics). Subsequently, the annual community primary energy use and $\mathrm{CO}_{2}$ emissions, with and without cogeneration, were calculated as will be described in more details later. Based on this, the cogeneration system performance within the base-line community was assessed using three performance indicators: the percentage of reduction in annual community primary energy use due to the use of cogeneration, the subsequent percentage of reduction in $\mathrm{CO}_{2}$ emissions; and the internal rate of return (IRR) of the cogeneration system. The impact of each design parameter on the performance of the cogeneration system was then assessed through developing design variations of the base-line community model representing selected assessment values for each design parameter. In total, 46 of these design variations were developed as shown in table 2. The same three performance indicators were then assessed for each design variation and a Multi-Attribute Decision Analysis methodology (MADA) was used to calculate the environmental, economic, and combined performances of the cogeneration system in each of these design variations relative to its performance within the base-line community (see Lippiatt (2002) for a discussion of MADA). These results were then used to evaluate the relative impact of each design parameter on the cogeneration system performance.

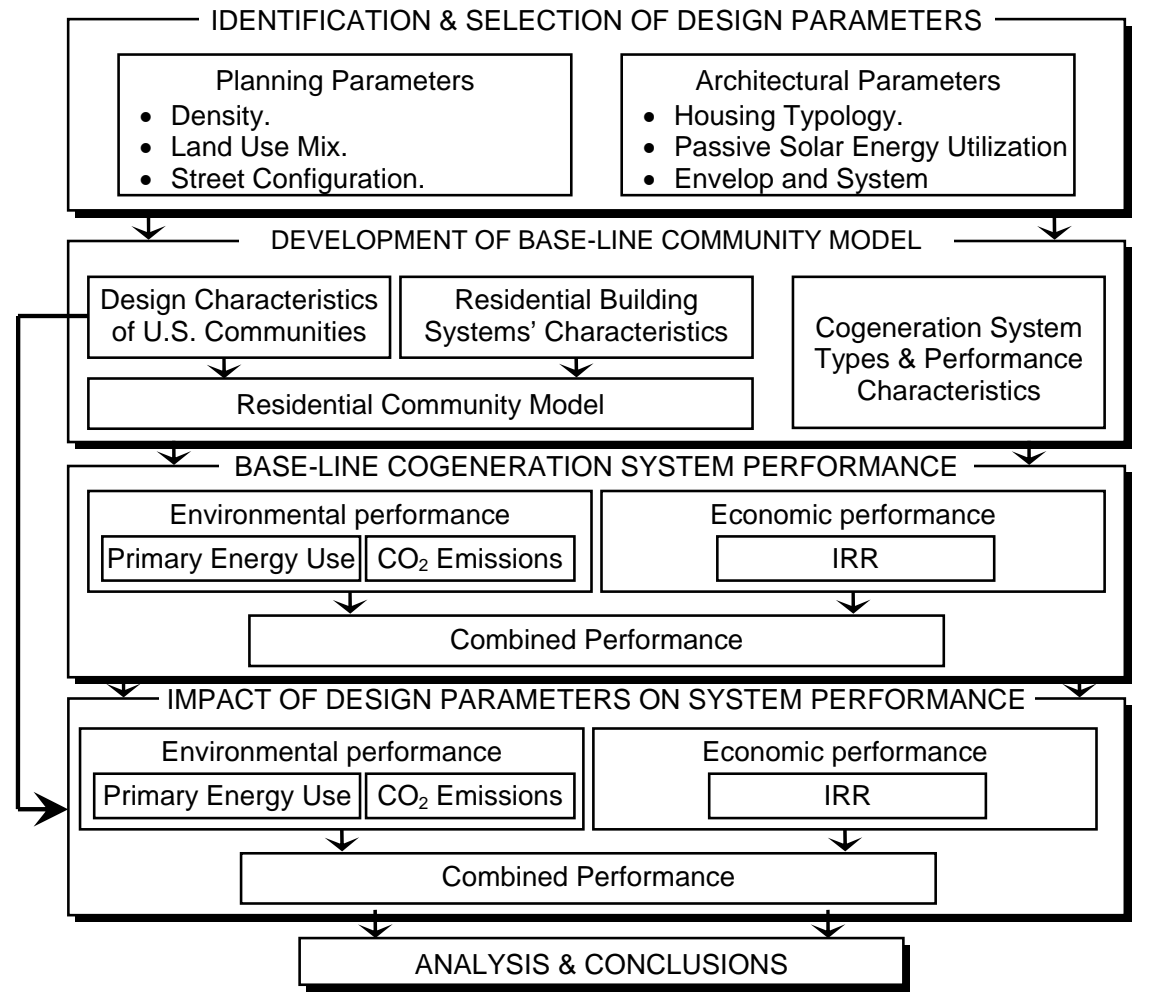

Figure 1: Schematic diagram of the research design

The cogeneration system performance assessment procedure involved several steps that utilized a number of existing software, tools, and databases. For both the base-line community case as well as each of the community design variations investigated in the study, assessing the performance of the cogeneration system involved first the development of building prototypes, either residential only or a mix or residential and commercial according to the design variation in question. In total, seven residential prototypes and 21 commercial prototypes, of different building typologies and sizes, were developed for this study using the simulation software eQUEST (Hirsch, 2003). The annual electrical and thermal energy consumptions of each model, without the cogeneration system, were simulated and the models were calibrated and the simulation results validated by comparing them to Energy Information Administration (EIA) energy use survey data. Following this, the annual primary energy use and annual $\mathrm{CO}_{2}$ emissions of the community, without cogeneration, were calculated by adding the electrical and thermal energy uses of each building and accounting for generation efficiencies and distribution losses. Based on this, the hourly electrical and thermal loads of the centralized cogeneration system were calculated by adding the loads resulting from each building, designing a community district heating network, calculating the thermal losses within this network in the selected climate, and adjusting the community thermal loads accordingly. The annual community electrical and thermal energy use with cogeneration was then simulated using the HOMER software (Lambert et al., 2006); and the annual primary energy use and $\mathrm{CO}_{2}$ emissions for the whole community were calculated similar to the "without cogeneration" case. The percentages of reduction in annual primary energy use and $\mathrm{CO}_{2}$ emission for the community due to 
the use of cogeneration were then calculated. These two values represented the environmental performance indicators used in this study. Finally, a life cycle cost analysis (LCCA) was conducted and the resulting IRR was calculated and represented the economic performance indicator used in the study. The three indicators were subsequently used to calculate an environmental and an economic performance for the cogeneration system, and the two performances were integrated into a combined performance following the MADA methodology mentioned previously. A more detailed description of the assessment procedures and the tools and assumptions involved can be found in Rashed-Ali (2006). The study utilized the climate of Helena, MT, which is considered as a representative city of the cold dry U.S. climate zone. The selection of the cold climate was based on previous studies (e.g. Gunes \& Ellis, 2003), which identified it as more favorable for cogeneration systems.

Table 1: Design characteristics of the base-line community model

\begin{tabular}{|c|c|}
\hline Design characteristics & Value \\
\hline \multicolumn{2}{|c|}{ Community design characteristics: } \\
\hline Community size & $300 \mathrm{du}$ \\
\hline Gross density & $4 \mathrm{du} / \mathrm{ac}$ \\
\hline Land-use mix & Single use residential \\
\hline Street configuration & Interconnected network / grid \\
\hline Housing typology & Single-family detached \\
\hline \multicolumn{2}{|c|}{ Single family house model characteristics: } \\
\hline Floor area & $197.9 \mathrm{~m}^{2}\left(2130 \mathrm{ft}^{2}\right)\left[167.2 \mathrm{~m}^{2}\left(1800 \mathrm{ft}^{2}\right) \mathrm{CFA}\right]$ \\
\hline Building form & Single-story, square, glazing distributed equally on four sides. \\
\hline \multicolumn{2}{|l|}{ Envelope characteristics } \\
\hline Wall R-value & $\mathrm{R}-25$ \\
\hline Ceiling R-value & $\mathrm{R}-49$ \\
\hline Slab perimeter insulation & $\mathrm{R}-14,0.37 \mathrm{~m}(4 \mathrm{ft})$ deep \\
\hline Window U-factor & 0.33 \\
\hline \multicolumn{2}{|l|}{ Building systems' efficiencies } \\
\hline Air-conditioning system & SEER 10 \\
\hline Furnace & AFUE $=78 \%$ \\
\hline Domestic hot water system & $E_{f}=0.594$ \\
\hline Internal loads: & $\begin{array}{l}\text { Based on } 2003 \text { international energy efficiency code (ICC 2003) and } \\
\text { performance analysis procedure developed for U.S. single family } \\
\text { homes by the Building America program (Herndon, 2005). }\end{array}$ \\
\hline \multicolumn{2}{|c|}{ Cogeneration system characteristics } \\
\hline System type & Reciprocating Internal Combustion (IC) Engine \\
\hline System size (power rating) & $250 \mathrm{~kW}$ \\
\hline Electrical efficiency (HHV) & $31.1 \%$ \\
\hline Thermal efficiency & $46.2 \%$ \\
\hline Overall system efficiency & $77.3 \%$ \\
\hline Operation strategy & Electric load-matching \\
\hline System configuration & Baseline electrical load, grid connected, auxiliary boiler, central pump. \\
\hline
\end{tabular}

\section{RESULTS AND ANALYSIS}

Figure 2 shows the results of the impact assessment conducted in the study. Terms listed on the $\mathrm{x}$-axis of the graph refer to the base-line community as well as the design alternatives, for both the planning and architectural design parameters, as described in table 2. While the y-axis represents the environmental \& economic performance of the cogeneration system within each alternative. The results revealed a number of significant findings. In general, variations in mix of uses and density clearly had the most impact on the system performance each resulting in up to $50 \%$ improvement in combined (environmental and economic) performance. With regard to use mix, a direct relationship was found between increasing the mixing of non-residential uses within residential communities and improvements in cogeneration system performance. Increasing this mix resulted in the most improvements in the cogeneration system's economic performance (up to 125\%) and combined performance (up to 53\%). These significant improvements are primarily due to the improved daily load profiles of the community through increasing the availability of day-time and all-night loads to balance the typical morning and evening residential loads. The largest increase in economic performance was achieved through providing a high level of use mix combined with an optimization of non-residential building typologies within the community to reduce the daily load variations. While increasing the mix of uses resulted in slight reductions in environmental performance, the considerable increase in economic and combined performances indicate the potential for using larger cogeneration system sizes which would improve this environmental performance while still achieving an acceptable economic one. The largest improvement in combined performance was achieved by: first, providing 
day-time electrical loads from building types such as retail, and office buildings; second, providing day-time nonseasonal thermal loads through the use of restaurants and a laundry, which increase the utilization of the thermal output of the cogeneration system; and third, providing all-night electrical and thermal loads through the use of a grocery and a bakery with 24 hour schedules. Similarly, increases in density were shown to have a significant positive impact on system performance especially with regard to economics resulting in up to $84 \%$ increase in IRR. This positive economic impact was primarily caused by reductions in the initial cost of the DHC network in the higher density design alternatives. Additional, though smaller, environmental improvements were also achieved with higher densities due to the reduced thermal energy losses in this network. The positive impact of higher density, however, is reduced as the community density increases. Finally, a density gradient resulted in a system performance comparable to a community with the equivalent average density.

Table 2: Measurement scales for selected design parameters

\begin{tabular}{|c|c|c|}
\hline Design parameter & & Design Alternatives \\
\hline \multirow[t]{3}{*}{$\begin{array}{l}\text { Planning } \\
\text { parameters }\end{array}$} & Street configuration & $\begin{array}{l}\text { 1) Interconnected network/grid }\left(\mathrm{BL}^{*}\right) \text {; } \\
\text { 2) Fragmented network; } \\
\text { 3) Modified, landscape-oriented network; } \\
\text { 4) Loops \& cul-de-sacs; } \\
\text { 5) Dendritic network. }\end{array}$ \\
\hline & Density of built form & $\begin{array}{l}\text { 1) } 1 \text { du/ac; } \\
\text { 2) } 4 \text { bldu/ac }\left(B L^{*}\right) \\
\text { 3) } 10 \text { du/ac; } \\
\text { 4) } 15 \text { du/ac; } \\
\text { 5) Density gradient. }\end{array}$ \\
\hline & Mix of uses & $\begin{array}{l}\text { 1) Single use (BL*); } \\
\text { 2) Low use mix (suburban areas); } \\
\text { 3) Medium use mix (main street grouping); } \\
\text { 4) High use mix (town center grouping); } \\
\text { 5) Optimized use mix. }\end{array}$ \\
\hline \multirow[t]{3}{*}{$\begin{array}{l}\text { Architectural } \\
\text { parameters }\end{array}$} & Housing typologies & $\begin{array}{l}\text { 1) Detached single family houses }\left(B L^{*}\right) \text {; } \\
\text { 2) Attached single family houses; } \\
\text { 3) Town-homes; } \\
\text { 4) Live-work units; } \\
\text { 5) Multi-family houses. }\end{array}$ \\
\hline & $\begin{array}{l}\text { Envelope \& building } \\
\text { system efficiencies }\end{array}$ & $\begin{array}{l}\text { 1) Energy code (IECC 2003) compliant }\left(\mathrm{BL}^{*}\right) \text {; } \\
\text { 2) } 5 \% \text { more efficient than IECC } 2003 \text {; } \\
\text { 3) } 10 \% \text { more efficient than IECC } 2003 \text {; } \\
\text { 4) } 15 \% \text { more efficient than IECC } 2003 \text {; } \\
\text { 5) } 20 \% \text { more efficient than IECC } 2003 .\end{array}$ \\
\hline & $\begin{array}{l}\text { Utilization of passive } \\
\text { solar energy }\end{array}$ & $\begin{array}{l}\text { 1) Orientation-neutral }\left(B L^{*}\right) \text {; } \\
\text { 2) Low renewable energy utilization; } \\
\text { 3) Medium renewable energy utilization; } \\
\text { 4) High renewable energy utilization; } \\
\text { 5) High utilization /reduced internal loads. }\end{array}$ \\
\hline
\end{tabular}

${ }^{*} \mathrm{BL}=$ base-line community characteristic

For the other design parameters, several alternative housing typologies also resulted in improved cogeneration system performance, the most notable of which were multi-family houses and live-work units. Multi-family houses performed the best resulting in an improvement in environmental performance of $24 \%$, and in economics of $6 \%$, adding to a $15 \%$ increase in combined performance; while live-work units resulted in larger economic improvements (46\%) combined by a $26 \%$ drop in environmental performance, thus resulting in an improvement of only $10 \%$ in combined performance. However, both typologies were evaluated with the base-line density of 4 du/ac, which is lower than the densities typically associated with them. This indicates a clear potential for further performance improvements with actual densities. Single family house size had a varied impact on system performance with large sizes resulting in better economics and smaller sizes resulting in better environmental performance. However, both impacts were not significant and the resulting combined performance for both sizes showed no noticeable change from the base-line. With regard to street configuration, the interconnected configuration resulted in the best cogeneration performance especially with regard to economics because of the impact of the increased network lengths in the other alternatives. On the other hand, increases in either envelope and building systems' efficiencies or in the utilization of passive solar energy within the community's buildings resulted in a reduction in economic performance due to the reduced availability of thermal loads and the 
subsequent increasing mismatch between the fuel to electricity ratio of the buildings and the heat to power ratio of the reciprocating engine based cogeneration systems used in the assessment.

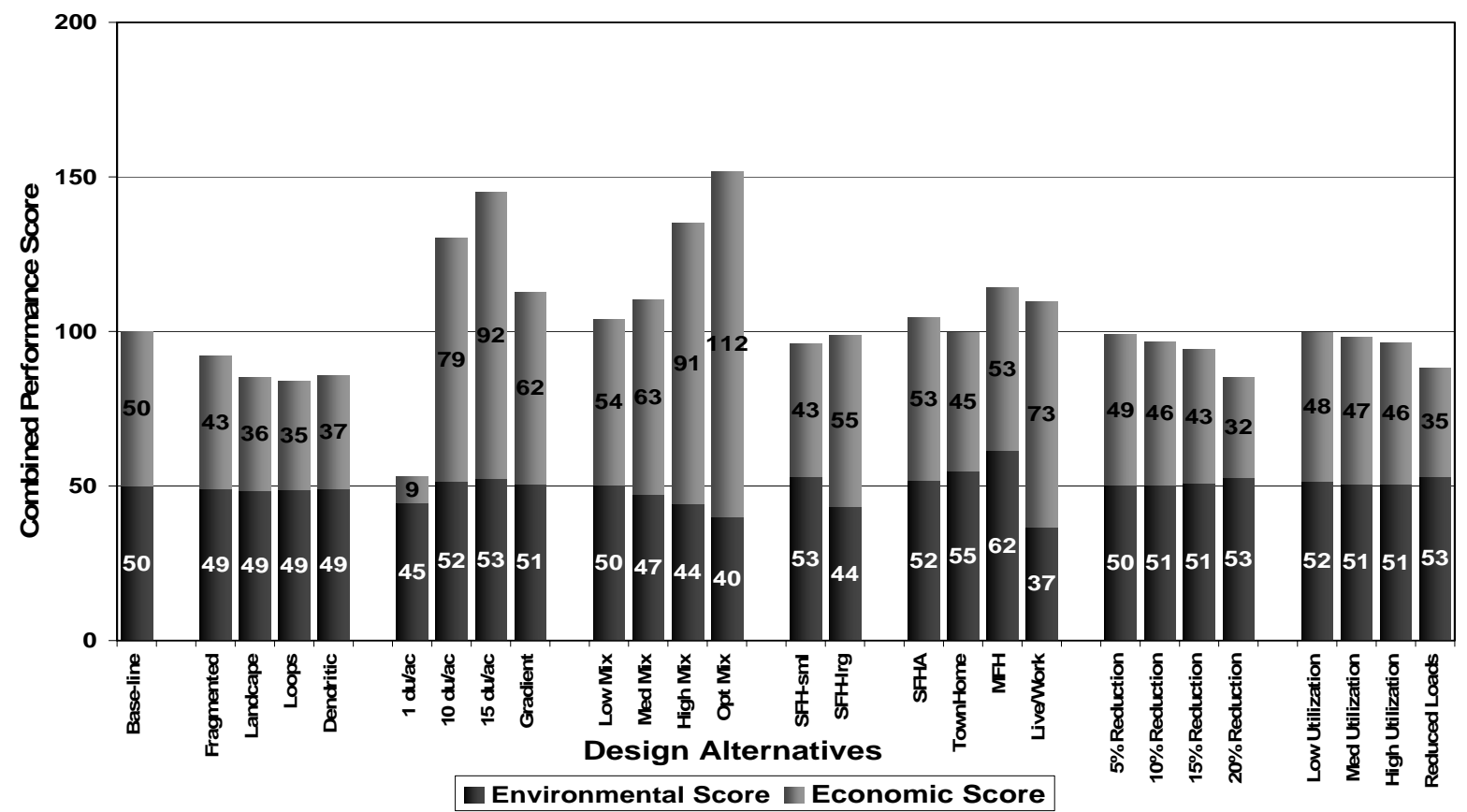

Figure 2: Summary of impacts of design parameters on combined performance of cogeneration system

\section{CONCLUSION}

This study represents part of the author's PhD research which aimed to identify the optimum community and cogeneration system design characteristics for residential communities utilizing cogeneration systems. This performance-based optimization aimed to improve the potential for using cogeneration systems in these communities thus achieving their potential environmental benefits. The results of this study can be utilized in one of two methods: 1) to inform designers of residential communities aiming to utilize cogeneration systems of the design parameters having the most impact on the system performance, and the design characteristics achieving the best performance, and 2) to assess the potential for integrating cogeneration systems in residential communities with a certain set of design characteristics and therefore identify potential market entry point for these emergent technologies. The major conclusions of the study can be summarized as follows:

1) The design of residential communities has a significant impact on the performance of cogeneration systems. Variations in density, mix of uses, and housing typology caused improvements as high as $120 \%$ in economic performance, and $52 \%$ in combined performance. This indicates a significant role for planners and architects in increasing the potential for utilizing cogeneration in residential communities through design optimization.

2) Through community design optimization, existing cogeneration technologies can be both economically feasible and result in considerable environmental benefits. Cogeneration systems investigated in this study resulted in up to $16.8 \%$ reduction in primary energy use and up to $33 \%$ reduction in $\mathrm{CO}_{2}$ emissions compared to the base-line case. Additionally, the majority of the design variations investigated in this study resulted in an economically feasible IRR (higher than 10\%).

3) Planning parameters generally had a larger impact on the cogeneration system performance than architectural ones. Increases in use mix and density resulted in the highest improvements in performance. With regard to architectural parameters, mixing of housing typologies offered the most potential for performance improvements. 4) A strong correlation was found between design characteristics identified as favorable for cogeneration system performance and characteristics of sustainable residential communities. These design characteristics included high density, high mix of uses, interconnected street configurations, and mixing of housing typologies, all of which are also characteristics of sustainable residential communities. This indicates the higher potential for integrating cogeneration systems in sustainable residential communities compared to conventional ones.

It should be noted that the results of this study are only applicable to the cold U.S. climate zone. As climate can significantly affect both community energy use characteristics and cogeneration system performance and possible configuraitons, repeating the study in other climate zones is recommended as an area of future study. 
Additional future studies recommended include investigating other cogeneration system configurations, such as the possible integration of active renewable energy systems (e.g. photovoltaics), investigating the impact of the size of the residential/mixed-use community on the performance of cogeneration systems, as well as investigating the impact of the proposed design changes on transportation energy use within the community.

\section{ACKNOWLEDGEMENT}

The study reported in this paper represents part of the author's PhD dissertation research conducted in Texas A\&M University. The author would like to thank Dr. Phillip Tabb, the Ph.D. dissertation committee chair, for his valuable support and guidance, as well as all the other members of the committee: Dr. Jeff Haberl, Dr. Robert Johnson, and Dr. Michael Neuman, for their insightful feedback. The work was partially funded through the William W. Caudill Research Fellowship in the Department of Architecture, Texas A\&M University; and the Fellowship for Advanced Study and Research of the American Institute of Architects (AIA) and the American Architectural Foundation (AAF) and the author would like to thank both organizations for their generous support.

\section{REFERENCES}

Barton, H. (ed.) 2000. Sustainable communities, the potential for eco-neighborhoods, Earth Scan Publications Limited, London, UK.

Braun, R., Klien, S., and Reindl, D. 2004. Considerations in the design and application of solid oxide fuel cell energy systems in residential markets. ASHRAE Transactions, 110(1):14-24.

Breheny, M. (ed.) 1992. Sustainable development and urban form, European Research in Regional Science 2, Pion Limited, London.

EIA (Energy Information Administration) 2004. Emissions of green house gases in the United States 2003, Energy Information Administration, U.S. Department of Energy, Washington, DC.

EIA (Energy Information Administration) 2005. Annual Energy Review 2004, Energy Information Administration, U.S. Department of Energy, Washington, DC.

Ellis, M. 2002. Fuel cells for building applications, American Society of Heating, Refrigeration, and AirConditioning Engineers, Atlanta, GA.

Grumman, D. (ed.) 2003. ASHRAE green guide, American Society of Heating, Refrigeration and Air-Conditioning Engineers, Atlanta, GA.

Gunes, M. and Ellis, M. 2003. Evaluation of energy, environmental, and economic characteristics of fuel cell combined heat and power systems for residential applications. Transactions of the ASME, 125:208-220.

Hendron, R. 2005. Building America research benchmark definition, updated 29 December 2004. National Renewable Energy Laboratories, Golden, CO.

Hirsch, J. 2003. eQUEST, quick energy simulation tool: Introductory tutorial. James J. Hirsch and Associates [http://www.doe2.com/download/equest/eQUESTv3-40_Tutorial.exe].

Houghton, T. 2000. The community energy utility, in H. Barton (ed.): Sustainable communities, the potential for eco-neighbourhoods, Earth Scan Publications Limited, London.

ICC (International Code Council) 2003. International energy efficiency code, 2003, International Code Council, Club Hills, IL.

Johansson, T., and Goldemberg, J. (eds.) 2002. Energy for sustainable development, a policy agenda, United Nations Development Program, New York, NY.

Knight, I. and Ugursal, I. (eds) 2005. Residential cogeneration systems: a review of the current technologies. A Report of Subtask A of Annex 42 of the International Energy Agency.

Lambert, T., Gilman, P., and Lilienthal, P. 2006. Micropower system modeling with HOMER, in: F. A. Farret, and Simões (eds.): Integration of alternative sources of energy, Wiley-IEEE Press, pp. 379-418.

Lippiatt, B. 2002. BEES® 3.0, Building for environmental and economic sustainability technical manual and user guide, National Institute of Standards and Technology, Gaithersburg, MD.

Owens, S. 1986. Energy, planning and urban form, Pion Limited, London, UK.

Phetteplace, G. 1995. Optimal design of piping system for district heating. CRREL Report. 95-17, Cold Regions Research \& Engineering Laboratory, US Army Corps of Engineers, Hanover, $\mathrm{NH}$.

Rashed-Ali, H. 2006. Cogeneration and community design: performance based model for optimization of the design of U.S. residential communities utilizing cogeneration systems in cold climates. PhD dissertation, Texas A\&M University, College Station, TX.

U.S. DOE (U. S. Department of Energy) 2003. The micro-CHP technologies roadmap, meeting 21st century residential energy needs, U. S. Department of Energy, Greenbelt, MD.

WADE (World Alliance for Decentralized Energy) 2003. Guide to decentralized energy technologies, World Alliance for Decentralized Energy, Edinburgh, UK.

WCED (World Commission on Environment \& Development) 1987. Our common future, Oxford University Press, Oxford, UK.

Williams, K.; Burton, E.; and Jenks, M. (eds.) 2000. Achieving sustainable urban form, E\&FN Spon, London, UK. 